\title{
Correlation between Healthcare Service Quality and HIV Testing Services Patient's Satisfaction in Kedungdoro Primary Health Care Surabaya
}

\author{
Arinda Agung Katritama ${ }^{1}$, Pudji Lestari ${ }^{2 *}$ (D) , M. Vitanata Arfijanto ${ }^{3}$ (D) \\ ${ }^{1}$ Faculty of Medicine, Universitas Airlangga Surabaya, Indonesia \\ ${ }^{2}$ Department of Public Medicine, Faculty of Medicine, Universitas Airlangga, Surabaya, Indonesia \\ ${ }^{3}$ Department of Internal Medicine, Faculty of Medicine, Universitas Airlangga, Surabaya, Indonesia - Dr. Soetomo General \\ Hospital Surabaya, Indonesia
}

\begin{abstract}
A B S T R A C T
Introduction: The service quality of primary healthcare centers, especially HIV testing services, must be improved. When the service quality is improved, there will be positive feedback such as patient satisfaction. Within the high patient satisfaction rate, People Living with HIV (PLWH) are expected to be more active productive and invite friends to check themselves so that the iceberg phenomenon will be revealed and prevention will be easier to control.

Methods: This research used an observational analytic design with a purposive sampling method. The total research sample was 189respondent assessed the questionnaire of five dimensions of service quality: tangible, reliability, responsiveness, empathy, and assurance. Three indicators of patient satisfaction were overall satisfaction, expectation, and experience.

Results: Among 189 respondents, mostly male with 129 responses or $68.3 \%$, according to age group, mostly from 20-25 years old age group with 88 answers or $46.6 \%$ and according to time visit, mostly first visit patient with 162 responses or $85.8 \%$. Service quality is mostly categorized in a good group with 173 respondents or $91.5 \%$. Inpatient satisfaction was mainly classified in a satisfied group with 157 respondents or $81.5 \%$. There was a positive correlation between service quality and patient satisfaction with a p-value $<0.01$ and a correlation coefficient of 0.632 . Conclusion: There is a correlation between every dimension of service quality which is tangible, reliability, responsiveness, empathy, and assurance with patient satisfaction of HIV testing services patient in Kedungdoro Primary Health Care Surabaya.
\end{abstract}

Keywords: Service Quality, Patient Satisfaction, HIV Testing Services, HIV

Correspondence: Pudji Lestari

E-mail: pules30@yahoo.com

Article history: $\bullet$ Received 13 July $2021 \bullet$ Received in revised form 18 September $2021 \bullet$ Accepted 2 November $2021 \bullet$ Available online 31 January 2022

\section{INTRODUCTION}

HIV infection mostly attacks productive age in Indonesia from 25-49 years old, mostly occurred in a heterosexual group, followed by homosexual group and other reasons which was not described. In 2015, there was 30,935 case of HIV infection and 6,373 cases of AIDS in Indonesia (Health Ministry of the Republic of Indonesia, 2016). HIV/ AIDS cases have a different characteristic compared to other disease cases. It is an iceberg phenomenon, where the number of cases cannot represent the actual number of HIV/AIDS cases in society (Hardisman, 2009).

The case of HIV infection in East Java supports the iceberg phenomenon of HIV. From data of HIV case in January-March 2016, there was 1,136 case of HIV, just 362 patient taking counseling and testing, and just 48 patient got the treatment and medical support. A similar case occurred in Surabaya (Health Ministry of the Republic of Indonesia, 2016).

Society's awareness about HIV/AIDS from early detection, counseling, treatment, and medical support if the patient is infected is essential. Primary health care like hospitals and Puskesmas (primary health care in Indonesia) has an important role in suppressing new HIV cases. Thus, health services, especially HIV testing services like VCT or PITC, must be improved. When the service quality is successfully improved, there will be positive feedback in the form of satisfaction from the patient (Hardisman, 2009).

According to Parasuraman Theory in 2001 about service quality, five dimensions determine the service quality. There are tangibles, reliability, responsiveness, assurance, and emphaty. According to Andreassen in 1994, customer satisfaction can be measured by three indicators: overall satisfaction, expectation, and experience (Andreassen, 1994).

\section{METHODS}

This study used an observational analytic research design with a cross-sectional approach. The researcher aims to test the hypothesis and explain the correlation without intervening in the variables by collecting data at one time (point time approach) (Nazir, 2003). The researcher used a purposive sampling method based on specific considerations that represent the population to be studied.The sample in this study was patients who met 
the following inclusion and exclusion criteria. Inclusion criteria consisted of patients who either the first time visit or repeated to the HIV testing services (VCT or PITC) at the Kedungdoro Primary Health Care Surabaya, age of the patient is between 20-49 years old, patients who are not mentally disturbed, and patients who can write and read. Exclusion criteria were patients in emergency condition.

The main instrument for data collection was the questionnaire self-completed by the customers, with assistance available if required. The questionnaire was developed based on Operational Standard Procedure for STIs and VCT Clinic published by Clinical Services Unit FHI Indonesia in 2007. The standard assessment for the questions is based on the SERVQUAL model from Parasuraman for service quality variable and customer satisfaction indicators from Andreassen for Patient's Satisfaction variable 4 (Parasuraman, 2001; Clinical Service Unit FHI Indonesia, 2007). The questions were on a 5-point Likert scale. The scores were coded 5 for strongly agree or strongly satisfied, 4 for agree or satisfied, 3 for neutral slightly agree, 2 for disagree or dissatisfied, and 1 for strongly disagree or highly unhappy.

The researcher tests the validity and reliability of the questionnaire, and the result of the validity test is valid, where each question has a significant correlation from the total score, which has a sig value $<0.05$. The research instrument was analyzed using Cronbach's $\alpha$ values for each question to test the reliability. The result of Cronbach's $\alpha$ is 0.939 , which is more than 0.388 ; the table's value is at a 5\% significance level (Heale \& Twycross, 2018).

The scale used in both variables is the ordinal scale, where the data calculation is based on Joshi et al. in 2015, which explains the use of Likert scales. The results of the total assessment of each variable in the questionnaire will be categorized into three groups, Good, Fair and Bad. The categories are used to determine whether the quality of the service has met patient satisfaction or not (Joshi et al., 2015). Then, the results were analyzed by Spearman's correlation rank test between service quality and its dimensions with patient satisfaction.

\section{RESULTS}

One hundred eighty-nine patients agreed to participate. The survey findings revealed that the sample of customers consisted of 129 respondents $(68.3 \%)$ male and 60 respondents $(31.7 \%)$ female. Based on the age group mostly from productive age, 88 respondents $(46.6 \%)$ were between the ages of 20-25. This study also reported that 163 respondents $(85.8 \%)$ were first visit patients.

\section{Service Quality}

In the service quality assessment, $173(91.5 \%)$ respondents rated good service quality. The results of service quality assessment consisted of the evaluation from five dimensions of service quality, Tangibles, Reliability, Responsiveness, Assurance, and Empathy. The review of each service quality dimension got a reasonable rate from the respondents. A total of $167(88.3 \%)$ respondents gave a reasonable rate intangibles dimension, $173(91.6 \%)$ respondents also rated the reliability dimension good, $152(80.5 \%)$ respondents rated the responsiveness dimension as good, 172 (91\%) respondents rated the assurance dimension good, and 157 $(83 \%)$ respondents rated the empathy dimension as good (Table 1).

\section{Patient's Satisfaction}

In the assessment of patient satisfaction, 154 (81.48\%) respondents felt satisfied with the service quality. The patient's satisfaction assessment consisted of three indicators of patient's satisfaction, overall satisfaction, expectation, and experience. The review of each indicator in patient's satisfaction got a satisfied category. A total of $146(77.24 \%)$ respondents assessed the overall satisfaction indicator as satisfied, $131(69.31 \%)$ respondents rated the expectation indicator that was satisfied, 137 (72.48\%) respondents rated the experience indicator that was satisfied (Table 1).

\section{Correlation between Service Quality and Patient's Satisfaction}

Based on the analysis of the results of the spearman's rho correlation test between service quality and patient satisfaction level in the HIV examination service at the Kedungdoro Health Center, Surabaya city showed a positive correlation, the probability value (sig) of 000 where the $p$-value is smaller than the $\alpha$ value of 0.05 which indicates there is a relationship between the quality of service and the level of patient satisfaction and for the correlation coefficient of 0.632 according to the Spearman rank correlation coefficient shows a strong relationship between the two variables (Table 1).

Table 1. Cross Table between Service Quality and Patient's Satisfaction

\begin{tabular}{lccccccccc}
\hline \multirow{2}{*}{$\begin{array}{l}\text { Service } \\
\text { Quality }\end{array}$} & \multicolumn{3}{c}{ Satisfied } & \multicolumn{2}{c}{ Enought } & \multicolumn{2}{c}{ Dissatisfied } & \multirow{2}{*}{ Total } \\
\cline { 2 - 7 } & $\mathrm{n}$ & $\%$ & $\mathrm{n}$ & $\%$ & $\mathrm{n}$ & $\%$ & $\mathrm{n}$ & $\%$ \\
\hline Good & 147 & 85 & 26 & 15 & 0 & 0 & 173 & 91.5 \\
\hline Enought & 7 & 43.8 & 9 & 56.2 & 0 & 0 & 16 & 8.5 \\
\hline Not Good & 0 & 0 & 0 & 0 & 0 & 0 & 0 & 0 \\
\hline Total & 154 & 81.5 & 35 & 18.5 & 0 & 0 & 189 \\
\hline
\end{tabular}

Note: Statistical Test Result $p=0.000 \varphi=0.632$ 
Table 2. Correlations Each Dimensions of Service Quality with Patient's Satisfaction

\begin{tabular}{|c|c|c|c|c|c|c|c|}
\hline \multirow{3}{*}{ Variable } & \multicolumn{4}{|c|}{ Patients Satisfaction } & \multirow{2}{*}{\multicolumn{2}{|c|}{ Total }} & \multirow{3}{*}{$\begin{array}{c}\text { Statistical Test } \\
\text { Result }\end{array}$} \\
\hline & \multicolumn{2}{|c|}{ Satisfaction } & \multicolumn{2}{|c|}{ Dissatisfaction } & & & \\
\hline & $\mathrm{n}$ & $\%$ & $\mathrm{n}$ & $\%$ & $\mathrm{n}$ & $\%$ & \\
\hline \multicolumn{8}{|l|}{ Tangibles } \\
\hline Good & 143 & 75.7 & 24 & 12.7 & 167 & 88.3 & $\mathrm{p}=0.000$ \\
\hline Enough & 10 & 5.3 & 11 & 5.8 & 21 & 11.2 & $\varphi=0.479$ \\
\hline $\mathrm{Bad}$ & 1 & 0.5 & 0 & 0 & 1 & 0.5 & \\
\hline Total & 154 & 81.48 & 35 & 18.51 & 189 & 100 & \\
\hline \multicolumn{8}{|l|}{ Reliability } \\
\hline Good & 148 & 78.3 & 25 & 13.2 & 173 & 91.6 & $\mathrm{p}=0.000$ \\
\hline Enough & 6 & 3.2 & 10 & 5.3 & 16 & 8.4 & $\varphi=0.611$ \\
\hline $\mathrm{Bad}$ & 0 & 0 & 0 & 0 & 0 & 0 & \\
\hline Total & 154 & 81.48 & 35 & 18.51 & 189 & 100 & \\
\hline \multicolumn{8}{|c|}{ Responsiveness } \\
\hline Good & 135 & 71.5 & 17 & 9 & 152 & 80.5 & $\mathrm{p}=0.000$ \\
\hline Enough & 19 & 10 & 16 & 8.5 & 35 & 18.5 & $\varphi=0.602$ \\
\hline $\mathrm{Bad}$ & 0 & 0 & 2 & 1 & 2 & 1 & \\
\hline Total & 154 & 81.48 & 35 & 18.51 & 189 & 100 & \\
\hline \multicolumn{8}{|l|}{ Guarantee } \\
\hline Good & 147 & 77.8 & 25 & 13.2 & 172 & 91 & $\mathrm{p}=0.000$ \\
\hline Enough & 7 & 3.7 & 10 & 0.53 & 17 & 9 & $\varphi=0.514$ \\
\hline $\mathrm{Bad}$ & 0 & 0 & 0 & 0 & 0 & 0 & \\
\hline Total & 154 & 81.48 & 35 & 18.51 & 189 & 100 & \\
\hline \multicolumn{8}{|l|}{ Empathy } \\
\hline Good & 134 & 70.9 & 23 & 12.3 & 157 & 83 & $\mathrm{p}=0.000$ \\
\hline Enough & 19 & 10 & 12 & 6.3 & 31 & 16.5 & $\varphi=0.467$ \\
\hline $\mathrm{Bad}$ & 1 & 0.5 & 0 & 0 & 1 & 0.5 & \\
\hline Total & 154 & 81.48 & 35 & 18.51 & 189 & 100 & \\
\hline
\end{tabular}

\section{DISCUSSION}

Patients who attend HIV testing services in Kedungdoro Primary Health Care are dominated by productive age patients and according to sex are dominated by men. These results are in agreement to the previous research and report from Indonesian Ministry of Health in 2017 (Health Ministry of the Republic of Indonesia, 2017). According to visit, patients who participated in HIV testing services at the Kedungdoro Primary Health Care were dominated by first visit patients.

The patients assessed HIV testing services at the Kedungdoro Primary Health Care were good and satisfied, in line with the results, accreditation of the Kedungdoro Primary Health Care which got a good accreditation, called Akreditasi Utama. The result also in line with Surabaya public health survey in 2018 (Surabaya City Government, 2018).

There is a correlation between the tangible dimensions on HIV testing services and the level of patient's satisfaction with moderate positive correlation (Table 2). The results of this study are in line with previous studies which showed a significant correlation between the tangible dimensions and the level of patient's satisfaction (Sutriani, 2013; Surabaya City Government, 2018; Fasika \& Gashaw, 2013; Dansereau et al., 2015).

There is a correlation between the Reliability dimensions on HIV testing services and the level of patient's satisfaction with a strong positive correlation, correlation between the Responsiveness dimension on HIV testing services and the level of patient's satisfaction with a strong positive relationship, correlation between the assurance dimension on HIV testing services and the level of patient's with a strong positive relationship, and correlation between the empathy dimension on HIV testing services and the level of patient's satisfaction with moderate positive relationships (Table 2). The results of this study are in line with previous studies which showed a significant relationship between the Reliability Dimensions and the level of patient satisfaction, a significant relationship between responsiveness dimensions and patient's satisfaction levels, a significant correlation between the assurance dimension and the level of patient satisfaction, a significant correlation between the empathy dimensions and the level of patient's satisfaction (Sutriani, 2013; Surabaya City Government, 2018; Fasika \& Gashaw, 2013; Dansereau et al., 2015; Bwanali \& Adamson, 2008; Surabaya City Government, 2018).

Every component in HIV testing services must be improved. Patients would be comfortable and satisfied after check themselves in the HIV testing services, it would bring a positive impact on those who were previously afraid to check their HIV status.

When the patients were satisfied, there will be no fear to check their HIV status, and the patient who had come, indirectly will told their friends to aware the importance 
of early detection of HIV and invited them to check their HIV status in HIV testing services.

\section{CONCLUSION}

Characteristics of respondents in HIV testing services at Kedungdoro Primary Health Care Surabaya are dominated by productive age. Men and first visit patients. The respondents who assessed the HIV testing services of Kedungdoro Primary Health Care were excellent and satisfied. There is a correlation between each dimension of service quality such as Tangible, Reliable, Responsive, Assurance, and Empathy with the level of patient satisfaction at Kedungdoro Primary Health Care Surabaya.

\section{ACKNOWLEDGEMENT}

he Authors thank Kedungdoro Primary Health Care for their support in the field investigation. All authors contributed to the discussion and interpretation of the results and drafting and editing the manuscript. The authors also thank all patients who participated in this study.

\section{CONFLICT OF INTEREST}

The authors declare there is no conflict of interest.

\section{REFERENCES}

Andreassen W. 1994. Satisfaction, loyalty, and reputation as indicators of customer orientation in public sector. International Journal of Public Sector Management 7(2):634.

Bwanali HJ, Adamson SM. 2008. Availability of supplies and motivations for accessing voluntary HIV counseling and testing services in Blantyre, Malawi. BMC Health Serv Research 8:17.

Clinical Service Unit FHI Indonesia. 2007. Standar
Operasional Prosedur Klinik IMS dan VCT.

Dansereau E, Masiye F, Gakidou E, et al. 2015. Patient satisfaction and perceived quality of care: evidence from a cross-sectional national exit survey of HIV and non-HIV service users in Zambia. BMJ 5:e009700.

Fasika D, Gashaw A. 2013. Assessment of Voluntary Counseling and Testing (VCT) Service Quality in Terms of Client Satisfaction; a Comparative Study between Public and Private Health Institutions in Addis Ababa, Ethiopia. Science Journal of Clinical Medicine 2(1):1-7.

Hardisman. 2009. HIV/AIDS in Indonesia: Iceberg Phenomenon and the Role of Primary Health Services. Jurnal Kesehatan Masyarakat Nasional 3(5).

Heale R, Twycross A. 2018. Validity and reliability in quantitative studies.

Health Ministry of the Republic of Indonesia. 2016. Situation Report on the Development of HIV/AIDS in Indonesia Jan-Mar 2016. Jakarta.

Health Ministry of the Republic of Indonesia. 2017. Situation Report on the Development of HIV/AIDS in Indonesia Jan-Mar 2017. Jakarta.

Joshi A, Kale S, Chandel S, Pal D. 2015. Likert scale: explored and explained. British Journal of Applied Science \& Technology 7(4):396-403.

Nazir M. 2003. Research methods. Jakarta, Ghalia Indonesia.

Parasuraman A. 2001. Service quality and productivity: a synergistic perspective. Managing Service Quality: An International Journal 12(1):6-9.

Surabaya City Government Community Satisfaction Survey 2018.

Sutriani. 2013. The relationship between the quality of HIV and AIDS services and patient satisfaction at Labuang Baji General Hospital Makassar. 